\title{
Dissonâncias E ANTAgonismos: A REPRESENTAÇÃo LITERÁRIA DE LIMA BarReto no Romance Clara dos Anjos
}

\author{
Ellen Margareth Dias Ribeiro ARAÚJO*
}

\begin{abstract}
RESUMO: Este artigo tem o propósito de analisar o romance Clara dos Anjos, de Lima Barreto, em diálogo com o contexto histórico-social da Primeira República brasileira. A análise busca aproximar os estudos críticos de Sérgio Buarque de Holanda, em Raizes do Brasil (2014), de Gilberto Freyre, em Casa grande e senzala (2001), Jorge Schwarz, em As ideias fora do lugar (2000), Antonio Candido, em Dialética da malandragem (1970) e Retrato do Brasil, de Paulo Prado (2012) com a representação literária do espaço físico e social dos subúrbios do Rio de Janeiro. Através desse estudo, buscamos fundamentar como a literatura de Lima Barreto reproduz, na ficção, as dissonâncias históricas, as ambivalências e os antagonismos sociais.
\end{abstract}

PALAVRAS-ChaVE: Lima Barreto. Clara dos Anjos. Preconceito Racial. Antagonismos Sociais.

\section{Introdução}

Lima Barreto pode ser considerado um escritor de transição. Viveu a transição da Monarquia para República e a transição do Realismo para o Modernismo. Sua obra está inserida no período que compreende a primeira República (1889-1930), marcada por modificações nas cidades, revoltas e crises sociais. Como cidadão brasileiro e escritor, sofreu influências dessas mudanças e procurou retratá-las em suas obras. O objetivo deste estudo é entender como se dá a representação literária

UFG - Universidade Federal de Goiás. Goiânia - GO - Brasil. 74690-900 - ellen_rib01@hotmail.com. 
desse processo social, que se pretende moderno, mas que perpetua e atualiza o passado colonial brasileiro. O romance escolhido para a análise é Clara dos Anjos, obra concluída por Lima Barreto (2011) em 1922, ano de sua morte, mas publicada somente em 1948.

Faremos algumas considerações sobre o panorama histórico-social da primeira República ou República Velha, a fim de entender como se configurou o regime republicano, na capital federal, Rio de Janeiro. Destacaremos também as consequências desse processo para o povo carioca. Em seguida, passaremos para forma e estética literárias empregadas por Lima Barreto em sua obra e, de maneira particular, em Clara dos Anjos (BARRETO, 2011), com o propósito de demonstrar o compromisso do autor com uma literatura militante, de denúncia e crítica social. É necessário frisar, porém, que a obra literária não é um espelhamento da realidade, pois é autônoma em sua forma de representação. No caso de Lima Barreto, as marcas da realidade fazem parte de seu projeto literário e nos ajudam a pensar aquele momento histórico.

\section{Nos tempos da República}

O regime republicano foi instituído por militares com promessas de progresso em questões políticas, econômicas e sociais. Como foi um ato que excluiu o povo, muitos nem sabiam o que significava aquele acontecimento. Longe de ser fruto do clamor do povo, a República veio para atender às necessidades de determinadas camadas da sociedade, principalmente aos interesses econômicos dessas classes sociais. O poder centralizou-se nas mãos dos militares, dos grandes proprietários rurais e comerciantes do setor cafeeiro e por eles era mantido por meio de fraudes, compra de votos, troca de favores e privilégios.

A República não alterou as estruturas socioeconômicas brasileiras: as desigualdades continuavam profundas. Com políticas de valorização do café e o crescimento da indústria brasileira, aumentou a imigração e a migração de pessoas do campo para as grandes cidades. Surgia uma nova configuração social que exigia mudança de costumes e adoção de uma forma de vida apropriada.

O Rio de Janeiro, capital da República e centro financeiro e econômico, precisava adaptar-se aos novos tempos, imitar o modelo europeu de civilização, a fim de criar uma imagem de prosperidade e credibilidade a qual extinguisse qualquer traço do atraso do passado. Era a regeneração do Rio de Janeiro - modernizar a cidade, banir o sujo e o feio. O historiador Nicolau Sevcenko (1999) explica como aconteceu essa transformação: 


\section{Dissonâncias e antagonismos: a representação literária de Lima Barreto no romance Clara dos Anjos}

Assistia-se à transformação do espaço público, do modo de vida e da mentalidade carioca, segundo padrões totalmente originais [...]. Quatro princípios fundamentais regeram o transcurso dessa metamorfose, conforme veremos adiante: a condenação dos hábitos e costumes ligados pela memória à sociedade tradicional; a negação de todo e qualquer elemento de cultura popular que pudesse macular a imagem civilizada da sociedade dominante; uma política rigorosa de expulsão dos grupos populares da área central da cidade, que será praticamente isolada para o desfrute exclusivo das camadas aburguesadas; e um cosmopolitismo agressivo, profundamente identificado com a vida parisiense. (SEVCENKO, 1999, p. 30).

Essas transformações sociais e urbanas agitaram a sociedade carioca da época e geraram uma clivagem entre os grupos tradicionais e a burguesia citadina, cosmopolita e progressista. O novo modelo empurrou as camadas mais populares para os subúrbios, onde os aluguéis eram mais baratos; retirou mendigos, prostitutas, ébrios e quaisquer outros grupos marginais do centro da cidade. As cerimônias populares tradicionais eram realizadas em áreas isoladas, para evitar o contato das duas sociedades. Delimitou-se, assim, o espaço que cada um desses grupos sociais deveria ocupar: o centro, para a elite e os subúrbios, para os pobres e marginalizados. Até certos comportamentos sociais, como a serenata e a boemia, foram condenados por desviarem-se do novo modelo de civilização.

A reação contra a serenata é centrada no instrumento que a simboliza - o violão. Sendo por excelência o instrumento popular, o acompanhante indispensável das "modinhas" e presença constante nas rodas de estudantes boêmios, o violão passou a significar, por si só, um sinônimo de vadiagem [...]. (SEVCENKO, 1999, p. 32).

A figura do seresteiro e do boêmio foi associada à indolência e à preguiça, imagem incompatível com os propósitos republicanos. $\mathrm{O}$ violão, o acompanhamento das modinhas populares e sempre presente nas rodas boemias e literárias, tornou-se um instrumento marginal. Nos tempos de República, tocar violão e cantar modinhas era sinal de malandragem e ócio. Restaram duas alternativas a esse grupo: arranjar um emprego no centro ou mudar para os subúrbios. Tratados como velhos hábitos coloniais, todas as formas de cultura e religiosidade populares foram estigmatizadas como atraso, ignorância e preguiça.

A primeira República, ao tentar transformar o Rio de Janeiro em uma Paris dos trópicos, acentuou ainda mais as desigualdades sociais e reforçou os antagonismos entre as classes. 


\section{Literatura militante}

A proclamação da República marcou sobremaneira a vida familiar e pessoal de Lima Barreto. O autor nunca ocultou o seu profundo desgosto com a nova ordem, que considerava como fonte de todos os infortúnios que acometiam a nação. $\mathrm{O}$ biógrafo Francisco de Assis Barbosa (1999), assegura que o escritor

[...] tinha consciência de que alguma coisa tinha que ser feita pelos escritores a serviço do povo brasileiro para retirá-lo da situação de miséria e ignorância, em que vivia abandonado pelos governos, consequência da própria organização social e política do país, quer sob o Império, quer sob a República. (BARBOSA, 1999, p. 14).

Os escritores, chamados pré-modernistas, que demonstraram maior interesse pela realidade social foram Euclides da Cunha e Lima Barreto. Contudo, as formas de abordagem literária dessa realidade se diferenciaram. Lima Barreto optou por falar do que ele vivia em seu cotidiano como mais um pobre e marginalizado pelo regime republicano.

O inconformismo e a revolta fizeram com que ele optasse por uma literatura militante, mais agressiva, instrumento de denúncia e transformação social. É nessa literatura que deixará o registro de sua missão, cumprida a despeito de todas as contrariedades. Um projeto que implicava possibilidades novas e originais na criação literária, mas que estavam em perfeita sintonia com a matéria tratada.

O método era sugerir uma representação mimética dos acontecimentos contemporâneos e dar uma feição exagerada às imagens para que o cotidiano perdesse seu aspecto de rotina, de normalidade e despertasse no leitor o sentimento e, posteriormente, uma tomada de posição, uma reação ao estímulo de sua arte. Eis suas convicções sobre os poderes e os fins da literatura:

[...] o homem, por intermédio da Arte, não fica adstrito aos preceitos e preconceitos de seu tempo, de seu nascimento, de sua pátria, de sua raça; ele vai, além disso, mais longe que pode, para alcançar a vida total do Universo e incorporar a sua vida na do Mundo. [...] Mais do que qualquer outra atividade de nossa espécie, a Arte, especialmente a Literatura, a que me dediquei e com que me casei; mais do que ela, nenhum outro qualquer meio de comunicação, entre os homens, em virtude mesmo do seu poder de contágio, teve, tem e terá um grande destino na nossa triste humanidade. (BARRETO, 1956, apud SEVCENKO, 1999, p. 168 e 195). 


\section{Dissonâncias e antagonismos: a representação literária de Lima Barreto no romance Clara dos Anjos}

Os temas são os mais variados possíveis: relações sociais e raciais; transformações sociais políticas, econômicas e culturais; crítica social, moral e cultural; discussões filosóficas e científicas; o cotidiano urbano e suburbano, etc. O interessante é que esses temas não podem ser dissociados ou isolados em suas narrativas, pois estão imbricados numa estratégia do autor.

Os seus personagens representam o Rio de Janeiro do seu tempo. Eles trazem o estigma do meio, da raça, de sua condição social, e constituem objeto da crítica de Lima Barreto. Nenhum aparece de forma decorativa, porque todos têm um papel importante a desempenhar em sua literatura. Destacam-se, em particular, os excluídos que acabam se misturando com outros tipos representativos.

Os ambientes também são os mais diversos: interiores domésticos burgueses e populares, estabelecimentos comerciais, bancas de jogo do bicho, festas e cerimônias burguesas e populares, bares e malocas, bordéis, pensões baratas, pardieiros, repartições públicas, prisões, hospícios, cortiços, favelas, trens, bondes, zonas rurais, ruas, estações ferroviárias, cais, portos, ministérios, cassinos, praias, jardins, subúrbios, centro da cidade, redações de jornais.

Podemos observar que o autor pretende apreender a realidade social na sua totalidade, em suas fissuras e tensões. Quanto ao processo narrativo, Lima Barreto procurava a combinação de gêneros, estéticas e estilos, aproximando-se da sátira e da paródia. Fugia de regras e preconceitos e buscava as mais variadas formas de expressão. Variar e criar - esse era o seu lema. Um procedimento comum era a valorização da variação sociolinguística do personagem, a fim de acentuar sua caracterização. O trecho a seguir é a fala de uma preta velha a respeito de Leonardo Flores, o poeta:

\footnotetext{
É "cosa"-feita! Foi inveja da "inteligença" dele! _ dizia uma preta velha Gentes da nossa "cô" não pode "tê" "inteligença"! Chega logo os "marvado" e lá vai reza e feitiço, "pá" "perdê"l o homem rematava a preta velha. (BARRETO, 2011, p. 68).
}

A ironia e a caricatura são os recursos mais característicos da obra barretiana. A ironia dá o tom da malícia ou humor, enquanto a caricatura exagera para expor deformações que despertem o desprezo nos leitores. A linguagem comum, antiretórica, direta, pouco metafórica, pouco imagística e altamente concreta, em conjunto com os procedimentos anteriormente citados, formam um todo coerente que garante a eficácia de sua obra perante o vasto público que esperava atingir.

Cauteloso, o autor preferiu usar os termos entre aspas. 


\section{O romance Clara dos Anjos}

Clara dos Anjos (BARRETO, 2011) conta a história de Clara, uma jovem mulata, filha de pais humildes e moradora do subúrbio carioca. Criada com muito recato e cuidado pelos pais, a moça, ingênua, sonhadora e ansiosa por viver a vida, deixa-se enganar por Cassi Jones, um malandro modinheiro, conhecido por seduzir as moças pobres e de cor, como Clara, e depois abandoná-las à própria sorte.

Nesse romance, Lima Barreto deixa um cruel registro da condição do mulato no Rio de Janeiro. Clara é iludida, não por acaso, por um rapaz branco e de melhor condição social. Tem-se, portanto, a imagem do mestiço como objeto daqueles que detêm uma posição superior na sociedade. $\mathrm{O}$ negro e o mulato compõem um grupo à parte, marginalizado e excluído.

Ressaltamos ainda a inovação, para a literatura da época, de discutir o tema do preconceito racial a partir de uma protagonista feminina. Entendemos que o escritor não se limita somente à questão racial, mas também pretende mostrar o indivíduo em sua fragilidade social. Numa sociedade tradicionalmente patriarcal, em cujos costumes ainda perduravam resquícios da escravidão recém-abolida, a protagonista Clara, além de mestiça e pobre, é mulher.

O historiador e crítico literário Sérgio Buarque de Holanda (1956), prefaciando Clara dos Anjos, ressaltou ser muito difícil escrever sobre os livros de Lima Barreto sem incidir no biografismo, ou seja, sem relacionar a trajetória de vida do escritor ao conjunto de sua obra. Realmente, por vida e obra estarem muito próximas, fica difícil para o leitor não associar fatos, personagens, ambientes e temáticas às experiências pessoais do autor. Ainda segundo Holanda (1956), Lima Barreto nem sempre se distanciou o bastante para dar lugar a uma verdadeira perspectiva artística, do que decorreram os defeitos da obra Clara dos Anjos.

A literatura excessivamente confessional desqualifica a obra de Lima Barreto como matéria artística? Seria uma visão bastante redutora analisar sua literatura sob essa perspectiva. É claro que sabemos dessa influência e o autor não nega isso, mas considerá-la um defeito, é um pouco imprudente, visto que o autor e sua obra encontram-se em conexão com contexto histórico-social em que se inserem.

O projeto de literatura engajada, de que se ocupou o escritor pré-modernista, não poderia deixar de lado o preconceito racial e social, do qual ele também foi vítima. Contudo, reconhecemos que há, sim, em Clara dos Anjos uma representação literária que extrapola a crítica social, pois alguns elementos da narrativa aproximamse da vida pessoal de Lima Barreto (2011). Essa característica torna-se evidente, principalmente, na caracterização de personagens, os quais lembram os dramas vividos pelo próprio escritor: são alcoólatras, boêmios, frequentadores de rodas literárias, apresentam distúrbios mentais, levam uma vida de miséria e decadência 


\section{Dissonâncias e antagonismos: a representação literária de Lima Barreto no romance Clara dos Anjos}

moral; alguns são negros ou mestiços. Marramaque e Leonardo Flores são dois personagens de Clara dos Anjos em cujos perfis identificamos traços do autor.

Embora atualmente fosse um simples contínuo de ministério, em que não fazia o serviço respectivo, nem outro qualquer, devido a seu estado de invalidez, de semi-aleijado e semiparalítico do lado esquerdo, tinha, entretanto, pertencido a uma modesta roda de boêmios literatos e poetas, na qual, a par da poesia e de coisas de literatura, se discutia muita política, hábito que lhe ficou. [...] Tendo tentado versejar, o seu bom senso e a integridade de seu caráter fizeram-lhe ver logo que não dava para a coisa. Abandonou e cultivou as charadas, os logogrifos, etc. Ficou sendo um hábil charadista e, como tal, figurava quase sempre como redator ou colaborador dos jornais, que os seus companheiros e amigos de boêmia literária, poetas e literatos, improvisavam do pé para a mão, quase sempre sem dinheiro para um terno novo. Envelhecendo e ficando semi-inutilizado, depois de dois ataques de apoplexia, foi obrigado a aceitar aquele humilde lugar de contínuo, para ter com que viver. Os seus méritos e saber, porém, não estavam muito acima do cargo. Aprendera muita coisa de ouvido e, de ouvido, falava de muitas delas. [...] Tendo vivido em rodas de gente fina — como já vimos —, e não pela fortuna, mas pela educação e instrução; tendo sonhado outro destino que não o que tivera; acrescendo a tudo isto o seu aleijamento - Marramaque era naturalmente azedo e oposicionista." (BARRETO, 2011, p. 23 e 24).

[...] Leonardo Flores, poeta, um verdadeiro poeta, que tivera o seu momento de celebridade no Brasil inteiro e cuja influência havia sido grande na geração de poetas que lhe seguiram. Naquela época, porém, devido ao álcool e desgostos íntimos, nos quais predominava a loucura irremediável de um irmão, não era mais que uma triste ruína de homem, amnésico, semi-imbelicizado, a ponto de não mais poder seguir o fio da mais simples conversa [...]. (BARRETO, 2011, p. 67).

[...] Pairei sempre no ideal; e se este me rebaixou aos olhos dos homens, por não compreender certos atos desarticulados da minha existência; entretanto, elevoume aos meus próprios, perante a minha consciência, porque cumpri o meu dever, executei a minha missão; fui poeta! Para isto, fiz todo o sacrifício. A Arte só ama a quem a ama inteiramente, só e unicamente; e eu precisava amá-la, porque ela representava, não só a minha redenção, mas toda a dos meus irmãos, na mesma dor. Louco?! Haverá cabeça cujo maquinismo impunemente possa resistir a tão inesperados embates, a tão fortes conflitos, a colisões com o meio tão bruscas e imprevistas? Haverá?

(BARRETO, 2011, p. 103). 
Percebemos, nos três excertos, a presença do Lima Barreto boêmio, frequentador das rodas literárias, o alcoolismo, a paixão pela literatura, o desgosto, o não reconhecimento, a decadência. Leonardo Flores seria um desdobramento do próprio autor, por sua trajetória e posicionamento militante como escritor negro e marginal. A figura de Marramaque denuncia a influência das rodas literárias; a cultura da oralidade, dos que aprendem "muita coisa de ouvido e, de ouvido, falava de muitas delas", a cultura superficial, de verniz; o azedume e a exclusão dos que não conseguem brilhar nas "rodas de gente fina".

O subúrbio, como espaço físico e social, funciona como elemento desencadeador de toda a trama. O autor de Clara dos Anjos expõe a precariedade do lugar, os tipos humanos que o habitam e o descaso das autoridades com saneamento básico e outras benfeitorias.

Há casas, casinhas, casebres, barracões, choças, por toda a parte onde se possa fincar quatro estacas de pau e uni-las por paredes duvidosas. [...] As ruas distantes da linha da Central vivem cheias de tabuleiros de grama e capim, que são aproveitados pelas famílias para coradouro. De manhã até a noite, ficam povoadas de toda espécie de pequenos animais domésticos [...] A gente pobre é difícil de se suportar mutuamente; por qualquer ninharia, encontrando ponto de honra, brigando, especialmente as mulheres. O estado de irritabilidade, provindo das constantes dificuldades por que passam, a incapacidade de encontrar fora de seu habitual campo de visão motivo para explicar o seu mal-estar, fazem-nas descarregar as suas queixas, em forma de desaforos velados, nas vizinhas com que antipatizam por lhes parecer mais felizes. [...] Por esse intrincado labirinto de ruas e bibocas é que vive uma grande parte da população da cidade, a cuja existência o governo fecha os olhos, embora lhe cobre atrozes impostos, empregados em obras inúteis e suntuárias em outros pontos do Rio de Janeiro. (BARRETO, 2011, p. 85-86).

Essa descrição do subúrbio assemelha-se ao procedimento adotado por Aluísio de Azevedo em $O$ Cortiço ([1890] 1997) e essa semelhança não é por acaso. Ainda sob a influência do Realismo e das correntes filosóficas e científicas do final do século XIX, Lima Barreto também acredita que naquele lugar esquecido pela modernização, o povo estaria condenado ao atraso e à mediocridade, sem chances de prosperar. Portanto, esse espaço torna-se propício a determinados comportamentos sociais autorizados pelo meio, onde impera a lei do mais forte.

O meio certamente funciona como determinante de certas atitudes dos personagens Clara dos Anjos e Cassi Jones. Mas outros fatores dissonantes e antagônicos, típicos da herança colonial patriarcal e escravista, também agem 


\section{Dissonâncias e antagonismos: a representação literária de Lima Barreto no romance Clara dos Anjos}

diretamente sobre outras relações travadas a partir do interesse de Cassi por Clara. Vejamos como Lima Barreto acentua esse antagonismo na composição de cada personagem:

Clara era uma natureza amorfa, pastosa, que precisava mãos fortes que a modelassem e fixassem. Seus pais não seriam capazes disso. A mãe não tinha caráter, no bom sentido, para fazê-lo; limitava-se a vigiá-la caninamente; e o pai, devido aos seus afazeres, passava a maioria do tempo longe dela. E ela vivia toda entregue a um sonho lânguido de modinhas e descantes, entoadas por sestrosos cantores, como o tal Cassi e outros exploradores da morbidez do violão. $\mathrm{O}$ mundo se lhe representava como povoado de suas dúvidas, de queixumes de viola, a suspirar amor [...].

[...] O seu ideal na vida não era adquirir uma personalidade, não era ser ela, mesmo ao lado do pai ou do futuro marido. Era constituir função do pai, enquanto solteira, e do marido, quando casada. [...] Não que ela fosse vadia, ao contrário; mas tinha um tolo escrúpulo de ganhar dinheiro por suas próprias mãos. Parecia feio a uma moça ou a uma mulher. (BARRETO, 2011, p. 106-107).

O narrador apresenta Clara dos Anjos como de "natureza elementar", o que traduz sua personalidade frágil, acomodada e romântica, tipicamente feminina nos padrões tradicionais. Destituída de uma individualidade social, Clara não almeja mudar sua condição de vida pelos estudos ou trabalho, prefere viver à sombra do pai ou do marido. "A filha do carteiro, sem ser leviana, era, entretanto, de um poder reduzido de pensar, que não lhe permitia meditar um instante sobre o destino, observar os fatos e tirar ilações e conclusões.” (BARRETO, 2011, p.107).

A descrição de Clara reforça os malefícios da formação machista, superprotetora, repressiva e limitadora reservada às mulheres na sociedade. A condição da personagem é agravada pela sua condição social e racial, que a expõe a todo tipo de discriminação. Lembrando que Clara dos Anjos, o nome escolhido por Lima Barreto para sua protagonista, é altamente sugestivo e irônico dentro do contexto da obra.

Era Cassi um rapaz de pouco menos de trinta anos, branco, sardento, insignificante, de rosto e de corpo; e, conquanto fosse conhecido como consumado "modinhoso", além de o ser também por outras façanhas verdadeiramente ignóbeis, não tinha as melenas do virtuose do violão, nem outro qualquer traço de capadócio. Vestiase seriamente, segundo as modas da rua do Ouvidor; mas, pelo apuro forçado e o degagé suburbanos, as suas roupas chamavam a atenção dos outros, que teimavam em descobrir aquele aperfeiçoadíssimo "Brandão", das margens da Central, que lhe talhava as roupas. A única pelintragem, adequada ao seu mister, 
que apresentava, consistia em trazer o cabelo ensopado de óleo e repartido no alto da cabeça, dividido muito exatamente ao meio - a famosa "pastinha". Não usava topete, nem bigode. O calçado era conforme a moda, mas com os aperfeiçoamentos exigidos por um elegante dos subúrbios, que encanta e seduz as damas com o seu irresistível violão. (BARRETO, 2011, p.27-28).

Cassi Jones é a verdadeira antítese de Clara na cor, na condição social e no caráter. Malandro e preguiçoso, ele ganhava algum dinheiro com rinhas de galo e jogo de dados. Participava de uma roda de meliantes e seu ofício predileto era seduzir moças pobres e de cor que moravam nos subúrbios. Cassi é produto de uma educação frouxa dispensada pela mãe permissiva, com ares de burguesa. É interessante perceber a estratégia de Lima Barreto em compor personagens tão distintos, mas que oferecem ao leitor um retrato das relações desiguais e opressoras na sociedade.

O narrador do romance Clara dos Anjos é mais um dentre os vários personagens da trama. Embora o foco narrativo seja em $3^{\text {a }}$ pessoa, procura manter a empatia e o diálogo com o leitor, com quem divide ironias, tristezas ou irritações.

Pobre Ernestina! Era tão alegre, tão tagarela, era moça, e bonitinha, na sua fisionomia miúda e na sua tez pardo-clara, um tanto baça, é verdade, mas não a ponto de enfeiá-la, quando conheceu Ataliba; e hoje? Estava escanzelada, cheia de filhos, a trair sofrimentos de toda a espécie, sempre mal calçada, quando, nos tempos de solteira, o seu luxo eram os sapatos! Quem te viu e quem te vê!

Cassi era assim e assim mantinha a sua fama de valente. Não julguem que tinha estima e amizade por esses rapazes que andavam sempre com ele. Ele não os amava como não amava ninguém e com ninguém simpatizava [...]. (BARRETO, 2011, p. 37, grifo nosso).

Ele não é um mero espectador dos fatos narrados, uma vez que se posiciona condenando Cassi, criticando Clara, elogiando o caráter de dona Margarida ou se apiedando de Marramaque. É possível associar sua fala à de Lima Barreto quando, em alguns trechos, o narrador deixa transparecer sua visão amarga e pessimista da vida.

Na sua cabeça, não entrava que a nossa vida tem muito de sério, de responsabilidade, qualquer que seja a nossa condição e o nosso sexo. Cada um de nós, por mais humilde que seja, tem que meditar, durante a vida, sobre o angustioso mistério da Morte, para poder responder cabalmente, se o tivermos que o fazer, sobre o emprego que demos à nossa existência [...]. (BARRETO, 2011, p. 107). 


\section{Dissonâncias e antagonismos: a representação literária de Lima Barreto no romance Clara dos Anjos}

\section{Literatura e sociedade}

A literatura militante de Lima Barreto é o registro artístico das transformações sociais, econômicas e políticas ocorridas na primeira República. A forma literária como o escritor apreende as tensões e os antagonismos sociais permite discuti-los a partir de obras que procuraram interpretar e refletir sobre as especificidades da formação da sociedade brasileira. Raízes do Brasil (2014), de Sérgio Buarque de Holanda, Casa grande e senzala (2001)), de Gilberto Freyre, Retrato do Brasil (2012), de Paulo Prado, Dialética da malandragem (1970), de Antonio Candido e As ideias fora do lugar (2000), de Roberto Schwarz possibilitam a problematização dos descompassos que Lima Barreto (2011) aponta no romance Clara dos Anjos.

A Abolição dos Escravos, em 1888, e a Proclamação da República, em 1889, marcaram o começo de um novo tempo no Brasil. Era impossível conviver com algo tão impolítico e abominável quanto à escravidão. O Brasil imperial e escravista destoava do resto do mundo civilizado como um símbolo de atraso e de desrespeito aos direitos humanos. Logo, a estrutura colonial, que ainda persistia no final do século XIX, precisava ser substituída por outra, similar aos padrões europeus de desenvolvimento. Sob a égide das ideias liberais e positivistas, o regime republicano impõe uma reprodução social completamente dissonante com a realidade brasileira ainda de mentalidade escravista e patriarcal. Porém, em terras brasileiras, tudo se configura de maneira bastante original. Gilberto Freyre (2001) denomina equilíbrio de antagonismos, o que ele classifica ser prática usual no Brasil, que tende a minimizar o choque entre as partes, no caso, liberalismo e escravismo, harmonizando-as de modo a amenizar seus efeitos. Roberto Schwarz (2000) confirma essa prática e fala da importância da literatura em representar essas dissonâncias:

Ao longo de sua reprodução social, incansavelmente, o Brasil põe e repõe ideias europeias, sempre em sentido impróprio. É nessa qualidade que elas serão matéria e problema para a literatura. $\mathrm{O}$ escritor pode não saber disso, nem precisa para usá-las. Mas só alcança uma ressonância profunda e afinada caso lhes sinta, registre e desdobre - ou evite - o descentramento e a desafinação. (SCHWARZ, 1969, p.29)

A prosa literária de Lima Barreto alcança essa ressonância afinada com o momento histórico em questão. O seu lugar de fala é de um escritor, que sentiu, mais do que qualquer um de seus contemporâneos, o preconceito racial e social e desdobrou a experiência pessoal em uma literatura de denúncia e debate. 
Como as dualidades e os antagonismos são revelados no romance Clara dos Anjos? Começaremos pela delimitação do espaço urbano no Rio de Janeiro. Em época de modernização, era preciso higienizar o centro da cidade, retirando de lá, aquilo que era incompatível com a nova imagem da cidade. A reurbanização implicou no desmanche de casas e na expulsão dos que lá moravam. O autoritarismo do governo fez com que a população pobre formada basicamente por negros, mestiços e imigrantes fosse deslocada para os subúrbios. No centro, a elite de pele branca, a beleza das vitrines da Rua do Ouvidor, os automóveis, a última moda em Paris; nos subúrbios, os negros e mestiços miseráveis, o trem da Central, a venda do Seu Nascimento, os vinténs contados para comprar o alimento do dia, os esquecidos pelas autoridades. Eis a grande fratura que a obra apresenta: o Rio de Janeiro cindido pelas diferenças sociais e pela linha férrea da Central do Brasil.

Sérgio Buarque de Holanda (2014, p. 35) observa que "trazendo de países distantes nossas formas de vida, nossas instituições e nossa visão de mundo e timbrando em manter tudo isso em ambiente muitas vezes desfavorável e hostil, somos uns desterrados em nossa terra". O centro do Rio de Janeiro é descrito uma única vez em todo o romance, quando Cassi Jones sai do subúrbio para depositar algum dinheiro na Caixa Econômica. Suas impressões revelam o significado de ser desterrado em nossa terra:

Não gostava mesmo do centro. Implicava com aqueles elegantes que se postavam nas esquinas e nas calçadas. Achava-os ridículos, exibindo luxo de bengalas, anéis e pulseiras de relógio. [...] Achava, tudo ridículo, exagerado, copiado, mas não sabia bem de que modelo. O que ele sentia diante daquilo tudo, daquelas maneiras, daqueles ademanes, daquelas conversas que não entendia, era a sua ignorância, a sua grosseria nativa, a sua falta de educação e de gosto. [...] A sua sensação era que estava em uma cidade estranha. [...] Na "cidade", como se diz, ele percebia toda a sua inferioridade de inteligência, de educação; a sua rusticidade, diante daqueles rapazes a conversar sobre coisas de que ele não entendia e a trocar pilhérias; [...]. (BARRETO, 2011, p. 133)

Lima Barreto coloca em questão o descompasso da modernização conservadora e excludente do Rio de Janeiro, que mais corresponde a uma evasão da realidade. O progresso prometido pela República limitou-se a alguns, enquanto a maioria foi condenada ao atraso. No final, Cassi chega à conclusão: “[...] todo aquele conjunto de coisas finas, atitudes apuradas, de hábitos de polidez e urbanidade, de franqueza no gastar, reduziram-lhe a personalidade de medíocre suburbano, de vagabundo doméstico, a quase coisa alguma [...]. (BARRETO, 2011, p.134). 


\section{Dissonâncias e antagonismos: a representação literária de Lima Barreto no romance Clara dos Anjos}

No subúrbio, Cassi Jones tinha "fama e valimento". Como se estabelecem as relações sociais nesse ambiente? O subúrbio carioca é o lugar dos homens livres e pobres, isto é, aqueles que vivem em dependência daqueles que têm. Essa relação de dependência, nossa herança colonial, é o favor, uma forma abrandada de escravidão, já que o favorecido está sempre cativo do favorecedor. De acordo com Roberto Schwarz (2000), o favor, pratica a dependência da pessoa, a exceção à regra, a cultura interessada, a remuneração e os serviços pessoais. Essa prática é também incompatível com as ideias liberais, mas é incorporada e modificada de uma maneira que passa a ser algo comum, rotineiro em todas as instâncias sociais. A troca de favores durante a primeira República mediava as relações entre as instituições, burocratas, militares, proprietários rurais, grandes comerciantes, como também as relações entre os homens livres e pobres dos subúrbios. Em Clara dos Anjos, esse tipo de mediação funciona como condição para a obtenção de certos privilégios ou facilidades.

Galos de briga eram a força de suas indústrias e do seu comércio [...] barganhava-os, com volta, vendia-os, chocava as galinhas, para a venda de frangos a criar e educar, presenteava as pessoas importantes das quais supusesse, algum dia, precisar do auxílio e préstimos delas contra a polícia e a justiça. (BARRETO, 2011, p, 34).

Contra a força não há resistência, pensou ele; o mais sábio era submeter-se. Não esperava mais que Cassi lhe oferecesse dinheiro, pedia-o. No começo o violeiro ia satisfazendo inteiramente os pedidos; depois, fazia-o pela metade; por fim, dizia que não tinha dinheiro e não lhe dava mais. Meneses, porém, continuava passivamente a desempenhar o seu indigno papel. Se não o achava decente, conformava-se diante da sua atroz e irremediável miséria. [...] (BARRETO, 2011, p.117).

[...] Cassi disse ao velho Lafões:

_ Estás aqui, estás na rua. Mandei o soldado falar ao meu chefe político: e ele vai interessar-se para seres solto. [...] $\mathrm{Na}$ verdade, Lafões foi solto; não houve, porém, qualquer intervenção do chefe político de Cassi. [...] Entretanto, o guarda das Obras Públicas sempre supôs que a sua libertação tivesse sido obra de Cassi, por isso lhe era grato e o defendia com todo ardor. (BARRETO, 2011, p. 48-49).

A prática do favor envolve o jogo de estima e autoestima. Em reconhecimento ao favor de tê-lo livrado da cadeia, o velho Lafões, amigo do pai de Clara, convida o modinheiro para o aniversário da moça. Cassi queria seduzir Clara; para isso, ele precisava de apoio. Cassi Jones realiza seus feitos porque consegue aliados 
por meio da troca de favores e bajulações. Já a relação de prestância entre Cassi e Meneses remete ao caráter destrutivo dessa dependência. O benefício de Cassi implica a derrota moral de Meneses. Sem que o dentista prático perceba, de pretenso favorecido, ele passa a favorecedor e não tem como se libertar do arranjo feito com Cassi, o que configura o escravismo.

Outro comportamento tipicamente brasileiro e que está diretamente relacionado ao favor, é o bovarismo ${ }^{2}$. Lima Barreto faz duras críticas a essa particularidade de país periférico em querer ser aquilo que não é. Acontece assim: a população citadina imita os padrões europeus, principalmente da França e da Inglaterra; os moradores dos subúrbios, por sua vez, tentam se aproximar dos valores e modos dos burgueses com pretensões de um lugar de prestígio e destaque entre os seus. É através da ironia e do sarcasmo que o autor trata dessa atitude tão característica do povo brasileiro:

Os seus cânticos, aos sábados (era o seu dia da semana de descanso sagrado), entoados quase de hora em hora, enchiam a redondeza e punham na sua audiência uma soturna sombra de misticismo. O povo não os via com hostilidade, mesmo alguns humildes homens e pobres raparigas dos arredores freqüentavam-nos, já por encontrar nisso um sinal de superioridade intelectual sobre seus iguais, [...]. (BARRETO, 2011, p. 19).

Cassi Jones de Azevedo era filho legítimo de Manoel Borges de Azevedo e Salustiana Baeta de Azevedo. O Jones é que ninguém sabia onde ele o fora buscar, mas usava-o, desde os vinte e um anos, talvez, conforme explicavam alguns, por achar bonito o apelido inglês. $\mathrm{O}$ certo, porém, não era isso. A mãe, nas suas crises de vaidade, dizia-se descendente de um fantástico Lorde Jones, que fora cônsul da Inglaterra, em Santa Catarina; e o filho julgou de bom gosto britanizar a firma com o nome do seu problemático e fidalgo avô. [...] Vestia-se seriamente, segundo as modas da rua do Ouvidor; mas, pelo apuro forçado e o degagé suburbanos, as suas roupas chamavam a atenção dos outros, [...]. O calçado era conforme a moda, mas com os aperfeiçoamentos exigidos por um elegante dos subúrbios, que encanta e seduz as damas com o seu irresistível violão. (BARRETO, 2011, p. 27-28).

Sua mulher [mãe de Cassi] não era lá muito querida, nem prezada. Tinha fumaças de grande dama, de ser muito superior às pessoas de sua vizinhança e mesmo às dos seus conhecimentos. O seu orgulho provinha de duas fontes: a primeira, por ter um irmão médico do Exército, com o posto de capitão; e a segunda, por ter andado no Colégio das Irmãs de Caridade. (BARRETO, 2011, p. 29).

\footnotetext{
2 Comportamento psicológico designado aos que tendem a aspirar por uma vida diferente da sua, idealizada e compensatória. Disponível: <www.dicionarioinformal.com.br/significado/bovarismo/5652>. Acesso em: 03 mar. 2017.
} 


\section{Dissonâncias e antagonismos: a representação literária de Lima Barreto no romance Clara dos Anjos}

Quando Sérgio Buarque de Holanda (2014) afirma que "somos desterrados em nossa terra", refere-se justamente ao "bovarismo nacional grotesco e sensaborão", nossa herança colonial, que nos induz a viver à mercê do outro, a fugir de nossa originalidade, a copiar modelos de cultura e civilização vindos de fora. Os preceitos republicanos acabaram incentivando essa postura, ao negar a nossa realidade biológica, da qual se envergonhava, e falsear outra mais adequada e aprovada pelos outros.

Paulo Prado, em Retrato do Brasil (2012), alerta para a dependência que sustenta a vida social, cultural e política do Brasil:

Tudo é imitação, desde a estrutura política em que procuramos encerrar e comprimir as mais profundas tendências da nossa natureza social, até o falseamento das manifestações espontâneas do gênio criador. [...] Nesta terra, em que quase tudo dá, importamos tudo: das modas de Paris - ideias e vestidos - ao cabo de vassoura e ao palito. Transplantados, são quase nulos os focos de reação intelectual e artística. Passa pelas alfândegas tudo que constitui as bênçãos da civilização: saúde, bem-estar material, conhecimentos, prazeres, admirações, senso estético. (PRADO, 2012, p. 139)

O bovarista do subúrbio usa de artimanhas para se evadir da realidade pela imitação. Nas passagens de Clara dos Anjos, transcritas anteriormente, vemos homens pobres e raparigas que frequentam a igreja protestante "dos bíblias" por achar bonita a fala do pastor inglês e porque estar ali já significa um prestígio perante os demais moradores do lugar. Cassi incorpora o bovarismo nacional grotesco ao "britanizar" o próprio nome por conta de uma imaginada descendência inglesa. Veste-se com esmero pra ser identificado como superior aos outros suburbanos.

Lima Barreto não escolheu por acaso o nome de seu personagem. $\mathrm{O}$ autor tinha total aversão pelos modelos importados, principalmente, os ingleses e americanos. Como criação literária, o personagem Cassi Jones agrega em si traços distintivos de nosso legado colonial, para o qual a crítica e a ironia do escritor estão voltadas.

A cordialidade é outro traço característico do brasileiro e, claro, de Cassi. Entende-se por cordialidade, o contrário de civilidade. Civilidade implica em regras de convivência, ética e moral. Cordialidade é o uso da polidez, que funciona como uma máscara social, para atingir determinados objetivos. De acordo com Sérgio Buarque de Holanda (2014), o homem cordial sente pavor em viver consigo mesmo, não consegue apoiar-se sobre si próprio e, por isso, precisa dos outros para exercer o seu poder. É um viver nos outros. O Cassi elegante, gentil e galanteador é o mesmo Cassi da roda de malandros, que explora Meneses e mata Marramaque a pauladas. 


\section{Ellen Margareth Dias Ribeiro Araújo}

O homem cordial julga suas ações conforme sua eficácia e não por elas serem boas ou más.

[...]. No subúrbio, tinha os seus ódios e os seus amores; no subúrbio tinha os seus companheiros, e a sua fama de violeiro percorria todo ele, e, em qualquer parte, era apontado; no subúrbio, enfim, ele tinha personalidade, era bem Cassi Jones de Azevedo [...]. (BARRETO, 2011, p. 133).

Cassi Jones não pode ser categorizado como anti-herói, pois a concepção romântica é simplificadora e pouco adequada à inscrição do personagem no momento histórico-social retratado. Ele tem uma identidade híbrida, por reunir valores antagônicos em perfeito equilíbrio na sua composição literária: o liberalismo burguês macaqueado ${ }^{3}$ numa reedição do patriarcalismo e do escravismo colonial. Bovarista e cordial, Cassi não é trabalhador nem romântico. É malandro.

Para discutir essa outra característica do personagem, precisamos entender a acepção que o termo assume na obra de Lima Barreto. Para Antonio Candido (1970), Memórias de um sargento de milícias, de Manuel Antônio de Almeida (1852) traz para a literatura brasileira o primeiro malandro carioca, Leonardo, sobre o qual, em Dialética da malandragem afirma não ser um pícaro ${ }^{4}$ tradicional por sua identificação com o folclórico, o cômico e o popular de seu tempo. Não podemos deixar de destacar que, mesmo com suas inovações estruturais, foi escrito no período do Romantismo e representa a sociedade carioca nos tempos de Dom João VI.

Por sua vez, Macunaíma, malandro-símbolo do Modernismo brasileiro, de acordo com seu criador Mário de Andrade, é o herói de nossa gente, mas não na concepção clássica de herói. Ele simboliza os traços múltiplos e contrastantes que caracterizam o povo brasileiro. Esse malandro, que também não é o pícaro tradicional, dialoga com Leonardo pela volubilidade, preguiça e incapacidade de produzir algo. Antonio Candido (1970) esclarece que

O malandro, como o pícaro, é espécie de um gênero mais amplo de aventureiro astucioso, comum a todos os folclores. [...] o pragmatismo dos pícaros [...] visa quase sempre ao proveito ou a um problema concreto, lesando frequentemente terceiros na sua solução [...]. (CANDIDO, 1970, p. 71, grifo nosso).

Leonardo e Macunaíma não se enquadram totalmente nesse perfil, pois não têm intenção de lesar ninguém. Leonardo, homem livre e pobre, é malandro de

3 Termo emprestado do poeta Manuel Bandeira, em "Evocação do Recife" de Libertinagem (1930). 4 pícca-ro in: Dicionário Priberam da Língua Portuguesa. 1. Falta de honra e de vergonha; 2. Patife, velhaco; 3. Malicioso, astuto; 4. Que com arte e dissimulação logra o que deseja. Disponível em:<https:// www.priberam.pt/dlpo/p\%C3\%ADcaro.> Acesso em: 04 mar. 2017. 


\section{Dissonâncias e antagonismos: a representação literária de Lima Barreto no romance Clara dos Anjos}

ocasião, movido por causalidades externas, vive ao sabor dos acontecimentos. Macunaíma gosta mesmo é de brincar. Não podemos dizer o mesmo de Cassi Jones, pois esse personagem excede na caracterização de pícaro, aproximando-o do arquétipo do trikster. ${ }^{5}$ Se Leonardo aproveitava das oportunidades para se dar bem, Cassi, movido por causalidades internas, faz as oportunidades aparecerem através de ardis e trapaças. Para ele não há ordem ou desordem, o certo ou errado, o justo e o injusto; o que lhe interessa é o prazer imediato e sair vitorioso nas demandas.

Interessante observar que Cassi Jones, por sua identidade híbrida, referida anteriormente, agrega mais essa duplicidade, o pícaro tradicional e o trikster - o perfil do malandro brasileiro.

Nunca suportara um emprego, e a deficiência de sua instrução impedia-o que obtivesse um acordo com as pretensões de muita coisa que herdara da mãe; além disso, devido à sua educação solta, era incapaz para o trabalho assíduo, seguido, incapacidade que, agora, roçava pela moléstia. A mórbida ternura da mãe por ele, [...] junto à indiferença desdenhosa do pai, com o tempo, fizeram de Cassi o tipo mais completo de vagabundo doméstico que se pode imaginar. É um tipo bem brasileiro. [...] Se já era egoísta, triplicou de egoísmo. [...] Nenhuma consideração de amizade, de respeito pela dor dos outros, pela desgraça dos semelhantes, de ditame moral, o detinha quando procurava uma satisfação qualquer. Só se detinha diante da força, da decisão de um revólver empunhado com decisão. Então, sim... (BARRETO, 2011, p. 35).

Nesse universo não existe a culpa, o remorso, nem mesmo a repressão da família ou da polícia. As vítimas que ele desonrava eram sempre moças de cor, de condição humilde, desde que não houvesse um parente capaz de vencer a influência de sua família. Ainda que os jornais e sua má fama no subúrbio denunciassem seus atos ignóbeis, ele continuava a praticá-los impunemente, amparado pelas relações de poder patriarcais.

A problemática fundamental de Clara dos Anjos é o preconceito racial. Optamos por discutir esse aspecto depois de apontar outros de igual relevância, porque eles também influenciam na reprodução literária que Lima Barreto faz sobre a condição do negro e do mestiço na sociedade carioca após a abolição da escravidão, em tempos de República.

Clara dos Anjos, protagonista do romance, é mulata, de origem humilde e mora no subúrbio do Rio de Janeiro. Qual seria o lugar da mulher mestiça e pobre

\footnotetext{
5 Na mitologia, no estudo do folclore e religião, um trickster é um deus, deusa, espírito, homem, mulher, ou animal antropomórfico que prega peças ou desobedece a regras e normas de comportamento. Disponível em: < https://pt.wikipedia.org/wiki/Trickster.> Acesso em: 04 mar. 2017.
} 
na sociedade republicana? Lima Barreto mostra que é o mesmo lugar que as negras e mulatas ocupavam nas casas-grandes, servindo para a satisfação sexual de seus senhores. Os mestiços continuavam sendo tratados como uma sub-raça indolente, ignorante e passiva. Associados à raça, o meio e a cultura também são fatores que incidirão fortemente na trajetória da personagem, levando-a a um desfecho tanto quanto previsível dadas as circunstâncias apresentadas. A visão negativa de Lima Barreto sobre a mestiçagem influi diretamente na composição de Clara dos Anjos, cujo nome é uma ironia à cor da pele e à ingenuidade da moça.

A única filha do carteiro, Clara, fora criada com o recato e os mimos que, na sua condição, talvez lhe fossem prejudiciais. Puxava ambos os pais. O carteiro era pardo-claro, mas com cabelo ruim, como se diz; a mulher, porém, apesar de mais escura, tinha o cabelo liso. [...] Raramente saía, a não ser para ir bem perto, à casa de Dona Margarida, aprender a bordar e a costurar, [...] Apesar de ser uso, nos subúrbios, irem as senhoras e moças às vendas fazer compras, Dona Engrácia, sua mãe, nunca consentiu que ela o fizesse, embora de sua casa se avistasse tudo o que se passava, no armazém do Seu Nascimento, fornecedor da família. Essa clausura mais alanceava sua alma para sonhos vagos, cuja expansão ela encontrava nas modinhas e em certas poesias populares. Com esse estado de espírito, o seu anseio era que o pai consentisse na visita do famoso violeiro, cuja má fama ela não conhecia nem suspeitava, devido ao cerco desvelado que a mãe lhe punha à vida; entretanto, supunha que ele tirava do violão sons mágicos e cantava coisas celestiais. (BARRETO, 2011, p. 50-51).

O autor coloca a condição de Clara incompatível com a educação que os pais lhe deram: nada que fosse capaz de prepará-la para a vida, para o enfrentamento das dificuldades. Reclusa, sem convivência, sem conhecimento dos perigos que corria, compensava sua solidão com sonhos de amor. Havia, ainda, o gosto pelas modinhas. O trovador Cassi soube tirar proveito dessa situação:

[...] simulava amor, escrevia detestavelmente cartas langorosas, fingia sofrer, emprega, enfim, todo o arsenal do amor antigo, que impressiona tanto a fraqueza de coração das moças daquelas paragens, nas quais a pobreza, a estreiteza de inteligência e a reduzida instrução concentram a esperança de felicidade em um Amor [...]. (BARRETO, 2011, p.64).

Assim, Lima Barreto, fundamenta sua proposição de que Clara dos Anjos é produto do meio, da raça e da cultura. Mas a discussão não se encerra apenas como uma relação de causa e efeito, bastante redutora. Essa representação literária 


\section{Dissonâncias e antagonismos: a representação literária de Lima Barreto no romance Clara dos Anjos}

do preconceito racial precisa ser situada e analisada num contexto mais amplo. É preciso refletir como os personagens Cassi Jones e Clara dos Anjos reeditam o legado colonial escravocrata em suas relações antagônicas.

Em Casa grande e senzala (2001), Freyre fala da miscigenação entre o branco e o negro como algo positivo, como uma adequação natural do português aos trópicos, harmonizando os antagonismos na colonização do país. Ele acrescenta, a preferência sexual do português pela mulata, enquanto as brancas eram escolhidas para casar. Enfatiza o sadismo do branco e o masoquismo da negra que se submete sexual e socialmente ao europeu.

Freyre (2001) mostra que a miscigenação racial não é uma debilidade e defende que a cultura patriarcal e escravocrata é que impôs a ideia de superioridade da raça branca e promoveu o preconceito racial. A obra de Lima Barreto é incompatível com a teoria freiriana, como perceberemos no trecho abaixo, nas reflexões de Marramaque, padrinho de Clara:

[...] ele sempre observou a atmosfera de corrupção que cerca as raparigas do nascimento e da cor de sua afilhada; e também o mau conceito em que se têm as virtudes de mulher. A priori, estão condenadas; e tudo e todos pareciam condenar os seus esforços e os dos seus para elevar a sua condição moral e social. (BARRETO, 2011, p. 49, grifo nosso).

Enquanto Lima Barreto condena Clara pela cor de sua pele e pela sua natureza elementar, a personagem Dona Margarida Weber, imigrante alemã, parece justificar a posição assumida pelo autor de que a raça teria uma influência maior sobre os indivíduos.

Dona Margarida era mulher alta, forte, carnuda, com uma grande cabeça de traços enérgicos, olhos azuis e cabelos castanhos tirando para o louro. Toda a sua vida era marcada pelo heroísmo e pela bondade. Embora nascida em outros climas e cercada de outra gente, o seu inconsciente misticismo humanitário, herança dos avós maternos, que andavam sempre às voltas com a polícia dos czares, fê-la logo se identificar com a estranha gente que aqui veio encontrar. Aprendeu-lhe a linguagem, com seus vícios e idiotismos, tomou-lhe os hábitos, apreciou-lhe as comidas, mas sem perder nada da tenacidade, do espirit de suite, da decidida coragem da sua origem. Gostava muito da família do carteiro; mas, no seu íntimo, julgava-os dóceis demais, como que passivos, mal armados para a luta entre os maus e contra as insídias da vida. (BARRETO, 2011, p. 153).

Dona Margarida mora no subúrbio, adaptou-se à cultura local, mas o caráter e disposição são os mesmos que herdara da família. Ela não se deixou influenciar pelo 
meio nem pela cultura daquela gente. Infere-se que, em Clara dos Anjos, perpassa a ideia de racismo biológico ${ }^{6}$, a partir das características atribuídas à Clara e aos outros mestiços e negros da narrativa.

Não podemos afirmar que essa seja a opinião pessoal do escritor mulato, que sofreu todo tipo de discriminação ou, se ele está tripudiando em cima da própria dor. Mesmo sendo acusado de não manter certo distanciamento de sua obra, em Clara dos Anjos, Lima Barreto (2011) pode ter assumido o ponto de vista da sociedade preconceituosa da época e, por isso esteja colocando o fator racial como a verdadeira desgraça na vida dos mestiços.

\section{Considerações finais}

Em Clara dos Anjos, Lima Barreto (2011) consegue alcançar o objetivo de sua literatura militante ao apontar dentro do contexto histórico-social da primeira República, os contrastes de uma sociedade cindida pelo espaço e pelas relações sociais. O escritor escolhe falar do lugar dos pobres e marginalizados - o subúrbio carioca - porque é o espaço onde as tensões estão postas de forma mais dura e explícita.

A concepção literária de Lima Barreto quebra com a hegemonia do beletrismo parnasiano e simbolista nos aspectos formais e estéticos. Mas, a grande novidade é conceber uma protagonista pobre e mestiça, de "natureza elementar" para o debate sobre o preconceito racial e social. Quando o autor promove o encontro entre a "natureza elementar" de Clara, com a malandragem de Cassi Jones, rapaz branco e de classe social superior, vêm à tona os antagonismos e descompassos da tradição patriarcal e escravocrata da colonização brasileira.

As relações entre os diferentes personagens e seus respectivos grupos sociais evidenciam as relações de poder também amparadas nessa mesma herança colonial mesquinha e ambivalente. A obra barretiana proporciona, a partir desses impasses, um diálogo com estudos teórico-críticos de História, Sociologia e Antropologia, que permitem entender como essas relações opressoras foram estabelecidas e assimiladas pela sociedade brasileira ao longo do tempo.

O romance Clara dos Anjos é a representação da manutenção dessas relações numa sociedade de consciência historicamente fraturada e em descompasso. A estratégia de Lima Barreto (2011) em aproximar os antagonismos resultou não só na crítica ao preconceito racial, mas também ao lugar social imposto à mulher negra ou mestiça pelo legado colonial.

6 Os estudos de evolução biológica do século XIX atribuem aos negros uma "inferioridade natural" devido à cor e tamanho do cérebro. Disponível em:< https://www.cartacapital.com.br/sociedade/zerohora-vamos-falar-de-racismo-6431.htm> . Acesso em: 06 mar. 2017. 


\title{
Dissonâncias e antagonismos: a representação literária de
}

Lima Barreto no romance Clara dos Anjos

A literatura militante cumpriu com o propósito de alcançar o leitor, não para a utópica transformação social que o autor tanto desejava, mas para discussão de temas sempre atuais que vão sendo reeditados pelos brasileiros.

\section{DissonanCES AND ANTAGONISMS: THE LITERARY REPRESENTATION OF LIMA BARRETO in the novel Clara dos Anjos}

\begin{abstract}
This article aims to analyze the novel Clara dos Anjos, by Lima Barreto, in dialogue with the social-historical context of the first Brazilian Republic. The analysis seeks to bring together the critical studies of Sérgio Buarque de Holanda in Raízes do Brasil (2014), Gilberto Freyre in Casa grande e senzala (2001), Jorge Schwarz in As ideias fora do lugar (2000), Antonio Candido in Dialética da malandragem (1970) and Retrato do Brasil by Paulo Prado (2012) with its physical and social representation of the suburbs of Rio de Janeiro. Through this study, we seek to substantiate how the literature of Lima Barreto reproduces the historical dissonances, the ambivalence and social antagonisms in fiction,.
\end{abstract}

KEYWORDS: Lima Barreto. Clara dos Anjos. Racial prejudice. Social antagonisms.

\section{REFERÊNCIAS}

ALMEIDA, Manuel Antônio de. Memórias de um sargento de milícias. ([1852] 1969). Disponível em: http://www.dominiopublico.gov.br/pesquisa/DetalheObraForm.do?select action=\&co_obra=1969>. Acesso em: 31 mai. 2018.

AZEVEDO, Aluísio de. O Cortiço. Fonte: AZEVEDO, Aluísio. O cortiço. 30. ed. São Paulo: Ática, 1997. (Bom Livro). Disponível em: <http://www.dominiopublico.gov.br/pesquisa/ DetalheObraForm.do?select_action=\&co_obra=1723>. Acesso em: 31 mai. 2018.

BANDEIRA, Manuel. Libertinagem. [1930]. Disponível em: <https://docslide.com.br/ documents/manuel-bandeira-libertinagempdf.html>. acesso em: 31 mai. 2018.

BARBOSA, Francisco de Assis. Prefácio. In: SEVCENKO, Nicolau. A literatura como missão. 4. ed. São Paulo: Brasiliense, 1999.

BARRETO, Lima. Clara dos Anjos. 4 ed. São Paulo: Martin Claret, 2011.

Impressões de leitura. São Paulo: Brasiliense, 1956, p. 66. 
CANDIDO, Antonio. Dialética da malandragem: caracterização das Memórias de um sargento de milícias. In: Revista IEB, n.8, São Paulo, USP, 1970, p. 67-89.

FREYRE, Gilberto. Casa-grande \& senzala: introdução à história da sociedade patriarcal no Brasil - 1. 45. ed. Rio de Janeiro: Record, 2001, p. 43-159.

HOLANDA, Sérgio Buarque de. Raízes do Brasil. 27. ed. São Paulo: Companhia das Letras, 2014.

p. 9-19.

. Prefácio. In: BARRETO, Lima. Clara dos Anjos. São Paulo: Brasiliense, 1956,

PRADO, Paulo. Retrato do Brasil: ensaio sobre a tristeza brasileira. 10 ed. São Paulo: Companhia das Letras, 2012.

SCHWARZ, Roberto. As ideias fora do lugar. In: Ao vencedor, as batatas: forma literária e processo social no início do romance brasileiro. 5. ed. São Paulo: Duas Cidades; Ed. 34, 2000.

SEVCENKO, Nicolau. A literatura como missão. 4. ed. São Paulo: Brasiliense, 1999.

Recebido em 10/02/2018.

Aprovado em 21/04/2018. 